\title{
EVALUATION OF DIFFERENT NUTRIENT MANAGEMENT PRACTICES IN YIELD OF DIFFERENT RICE CULTIVARS IN LAMJUNG DISTRICT OF NEPAL
}

\author{
S. Ranabhat* and L.P. Amgain \\ Institute of Agriculture and Animal Science, Lamjung Campus, Nepal \\ *Corresponding author's email: sabita.ranabhat12@gmail.com
}

\begin{abstract}
A field experiment was conducted on farmer's field at two sites of Lamjung district of Nepal viz. Bhotewodar and Sundarbazaar to evaluate the performance of two commonly grown rice varieties viz US-382(hybrid) and Ramdhan (improved) under two nutrient management practices [Nutrient Expert ${ }^{\circledR}(\mathrm{NE})$ rice model recommendation, and government recommendation(GR)].Four replicates of four treatments were arranged in randomized completely block design. Rice varieties responded differently under the different nutrient management practices in terms of plant height, grains per panicle, sterility\%, panicle weight, grain yield at 15\% moisture, straw yield and harvesting index. The highest grain yield was obtained from NE field of US-382 variety which was followed by GR for US-382, NE for Ramdhan and GR for Ramdhan variety. NE based practices for US-382 variety produced higher biological yield as compared to GR. NE estimated attainable rice yield provided by the software compared with actual rice yield from the trials in farmer's field and NE-based fertilizer recommendations proved the validity in reaching the yield targets estimated by the software. The observed rice yields recorded in the trials were higher than the NE estimated attainable yields, so NE recommendation for US-382 variety was found better over GR
\end{abstract}

Key words: Government Recommendation; Hybrid; Nutrient Expert; Rice; Yield

\section{Introduction}

Rice (Oryza sativa L.) is one of the most important cereal crops in Nepal with area, production and average yield of 1.43 million ha, 4.8 million tons, and $3.35 \mathrm{t} \mathrm{ha}^{-1}$, respectively (MoAD, 2014/15). Increased yield potential of rice is necessary for satisfying the food requirement of the country (NARC, 2013). In context of Nepal, rice is mainly grown in swampy areas, which are very limited and as such cannot meet rice demand of increasing population. Beside this, less attention is still being given to upland rice production in Nepal. There are large gaps between crop yield potential and farmers' yields. The lower yield persists in the farmer's field mainly due to the improper fertilizer management (Ladha et al., 2005).

Despite the government's efforts for making the country self-sufficient in rice production, both the production and productivity is quite low as compared to the global average productivity. Of all external inputs required for crop production in Nepal, nutrients are the most limiting factor for rice production in Nepal. Fertilizer recommendations in Nepal by government bodies and research stations are based on blanket recommendations for a region without considering the site-specific needs of soil and weather conditions. This has resulted in under-fertilizer rate and over fertilizer rate. Farmers are still unknown about the rate of fertilizer to be used in rice field. In mid-hill, farmers are using the fertilizer as per their wishes and as recommended by the local farmer leader. Most of the people use the fertilizers when they see the problem of insects or pest as well as the water available. They are unknown about the relationship between the water amount and fertilizer requirement.

On the other hand, site specific nutrient management is a new concept for Nepal. NE is a simple computer based decision support system (DSS) or delivery tool that can rapidly provide nutrient recommendations for $\mathrm{N}, \mathrm{P}$ and $\mathrm{K}$ for crops for individual farmer's fields in presence or absence of soil testing results. However, this approach has not much been used in Nepal especially in the hilly districts. The objective of this study was to compare the effectiveness of Nutrient Expert (NEß) model nutrient recommendation and government recommendation method on crop yield in rice crop (Dobermann et al., 1996). This research aims at identifying the best ways of managing the rice nutrition for sustained higher rice production in the rainfed rice ecosystem in the mid hills of Nepal. 


\section{Materials and Methodology}

This research was conducted in Sundarbazar and Bhotewodar of Lamjung District Nepal in collaboration with FORWARD (Nepal), NRNA-NCC (Australia) and IPNI. Farmers of Sundarbazaar municipality of Lamjung who mostly used to grow rice were selected. The questionnaire were developed and interview was taken by visiting the individual farmer's field. We recorded the detail information about their rice cultivation practices and their nutrient management practices. The data were entered into NE Rice software and different nutrient dose of nitrogen, phosphorus and potassium through urea, DAP and MOP respectively were recommended for different farmer field. We selected two commonly grown rice varieties US382(hybrid) and Ramdhan (improved). These varieties were brought from local agrovet.

The nursery seed bed was prepared in the field of Lamjung campus. The seed bed were raised as per the farmer practices. Seed of two varieties of rice were sown along with application of FYM in the prepared bed. After 22-26 days, it was transplanted in different field according to the treatment set-up. Field was prepared first by using an oxen since tractor was not feasible in our working field. A deep ploughing was done a week before planting. Final field preparation was done a week after first ploughing. Randomized Complete Block Design with 4 treatment and four replication was set up. Treatments were Nutrient Expert recommended fertilizer rates for US-382 variety, Nutrient Expert recommended fertilizer rates for improved variety, Government recommended fertilizer rate for US382 variety and Government recommended fertilizer rate for improved variety. Plots (each of $100 \mathrm{~m}^{2}$ ) were prepared by tillage operations and applied fertilizers for treatment plots as are shown in Table 1.

Harvesting was done manually on November of 2015. Observation of No. of effective tiller per hill, Length and weight of panicle, Number and weight of grains per panicle, Test weight, straw and grain yield, Harvest index was taken.
Comparison of Nutrient Expert ${ }^{\circledR}$ (NE) estimated attainable rice yield provided by the software with actual yield from the farmer field trial was done. Data entry and analysis was done by using: Microsoft word for data processing, MS excel for data input, table, charts, graphs \& simple statistical analysis, IBM SPSS Statistics 16, Gen stat 2003 for statistical analysis. ANOVA was done at $0.05 \%$ level of significance.

\section{Results and Discussion}

The result showed that relative performance of NE US-382 rice was found better over GR. The mean data showed that plant height at the time of harvesting, grain per panicle, panicle weight, Harvesting Index , sterility\%, paddy yield were significantly influenced by the the different treatment.

The mean data presented in Table 2 showed that the highest plant height was found in US-382 rice under NE treatment (103.2) which was followed by GR treatment for US-382 $(102.3 \mathrm{~cm})$, NE treatment for Ramdhan (86.08) and GR Ramdhan $(78.95 \mathrm{~cm})$. Table 2 shows that plant height increased with balanced fertilizer used that required by the site field. Salam et al. (2011) and Haq et al. (2002) reported that highest plant height was found in high and balanced NPK fertilizer.

Highest grain yield at $15 \%$ moisture was obtained in the NE field for the US-382 rice i.e. (7.362 t/ha) which was followed by GR for US-382 variety (6.12t/ha), NE for improved variety (5.20 t/ha) and GRI (4.70 t/ha). Rice yields were far more stable and varied within a short range as the NE recommendation for each individual farmer was designed to achieve the maximum attainable yield of HYV rice in the kharif season. Studies using NE for other crops like maize and wheat also showed significant yield advantage from the tool-based fertilizer recommendation as compared to existing practices (Satyanarayana et al., 2012; Sapkota et al., 2014).Dobermann et al., 2004 also reported the same result that NE or SSNM practice showed the highest yield than the farmer practice.

Table 1: Fertilizer applications for different treatments under study

\begin{tabular}{lllll}
\hline Fertilizers & NE(US-382) & NE(Improved) & GR(Hybrid) & GR(Improved) \\
\hline $\mathrm{N}_{2}\left(\mathrm{~kg} \mathrm{ha}^{-1}\right)$ & 126 & 97 & 120 & 100 \\
& $(38: 44: 44)$ & $(29: 34: 34)$ & $(36: 42: 42)$ & $(30: 35: 35)$ \\
$\mathrm{P}_{2} \mathrm{O}_{5}\left(\mathrm{~kg} \mathrm{ha}^{-1}\right)$ & 27 & 22 & 45 & 30 \\
$\mathrm{~K}_{2} \mathrm{O}\left(\mathrm{kg} \mathrm{ha}^{-1}\right)$ & 57 & 40 & 45 & 30
\end{tabular}


Table 2 (a): Yield attributes of different rice cultivars under different nutrient management practices in Lamjung

\begin{tabular}{|c|c|c|c|c|c|c|}
\hline Fertilizer practice & Variety & ET/ hill2 & PH & Straw yield $\left(\right.$ tha $\left.^{-1}\right)$ & BY $\left(\right.$ tha $\left.^{-1}\right)$ & HI \\
\hline \multirow[t]{2}{*}{$\mathrm{NE}$} & US-382 & 18.6 & $103.2^{\mathrm{a}}$ & $9.93^{\mathrm{a}}$ & $17.298^{\mathrm{a}}$ & $42.40^{\mathrm{ab}}$ \\
\hline & Ramdhan & 16.65 & $86.08^{\mathrm{cd}}$ & $7.37^{\mathrm{bc}}$ & $12.57^{\mathrm{bc}}$ & $41.71^{\mathrm{ab}}$ \\
\hline \multirow[t]{6}{*}{ GR } & US-382 & 16.95 & $102.3^{\mathrm{ab}}$ & $8.72^{\mathrm{ab}}$ & $14.85^{\mathrm{ab}}$ & $41.12^{\mathrm{b}}$ \\
\hline & Ramdhan & 16.02 & $78.95^{\mathrm{d}}$ & $6.20^{c}$ & $10.90^{c}$ & $42.79^{\mathrm{ab}}$ \\
\hline & Sig & $n s$ & $* *$ & $* *$ & $* *$ & $*$ \\
\hline & S Em $( \pm)$ & 1.032 & 2.23 & 0.466 & 0.596 & 1.289 \\
\hline & LSD (0.05) & 3.302 & 7.14 & 1.491 & 1.907 & 4.125 \\
\hline & CV\% & 15.7 & 4.8 & 11.1 & 12.8 & 9.2 \\
\hline
\end{tabular}

Table 2 (b): Yield attributes of different rice cultivars under different nutrient management practices in Lamjung

\begin{tabular}{|c|c|c|c|c|c|c|}
\hline Fertilizer practice & Variety & PL (cm) & FG/panicle & Pw (g) & Test weight (g) & Sterility (\%) \\
\hline \multirow[t]{2}{*}{$\mathrm{NE}$} & US-382 & 24.9 & $157.10^{\mathrm{b}}$ & $5.452^{\mathrm{a}}$ & 24.22 & $16.65^{\mathrm{b}}$ \\
\hline & Ramdhan & 24.3 & $90.07^{\mathrm{c}}$ & $2.735^{\mathrm{b}}$ & 23.72 & $27.94^{\mathrm{a}}$ \\
\hline \multirow[t]{6}{*}{ GR } & US-382 & 24.1 & $205.75^{\mathrm{a}}$ & $5.702^{\mathrm{a}}$ & 23.75 & $14.57^{\mathrm{b}}$ \\
\hline & Ramdhan & 24.9 & $82.25^{\mathrm{c}}$ & $2.372^{\mathrm{b}}$ & 22.85 & $27.70^{\mathrm{a}}$ \\
\hline & Sig & $n s$ & $* *$ & $* *$ & $n s$ & $* *$ \\
\hline & $\mathrm{S} \operatorname{Em}( \pm)$ & 0.99 & 9.21 & 0.42 & 0.92 & 1.67 \\
\hline & LSD (0.05) & 3.17 & 29.46 & 1.34 & 2.97 & 5.35 \\
\hline & $\mathrm{CV} \%$ & 6.9 & 13.1 & 23 & 8 & 14.6 \\
\hline
\end{tabular}

The positive correlation and significant regression equation between grain yield of rice with plant height at the time of harvesting, filled grains/panicle, panicle weight were recorded, while the negative correlation and least contribution with percentage sterility was clearly depicted between different sets of treatments in Lamjung (Fig. 1)

The mean data presented in Table2 showed that highest straw yield i.e. (9.93 t/ha) was obtained in the NE US-382 field followed by GR US-382 field i.e (8.72 t/ha) and NE Ramdhan(7.37t/ha) . Similar results were reported by Mirza et al. (2010). Nitrogen influenced vegetative growth in terms of plant height and number of tiller hill-1 which resulted in increased straw yield (Table 2). Similar trend of straw yield was also reported by Srivastava et al. (1987), Kanda and Dixit (1996). The highest filled grain per panicle was found in GR for US-382 variety i.e. (205.75) followed by NE for US-382 (157.10) and the lowest filled grain per panicle was found in NE for Ramdhan variety, i.e. (82.25).Panicle weight of US-382 and improved variety of rice was found highly significant in NE treatment (Table2). Highest panicle weight was found in GR for US-382 rice, i.e. $(5.70 \mathrm{~g})$ which was followed by NE US-382, i.e. (5.45g), FFP (3.095), NE improved (2.73g) and lowest panicle wt. was found in GR for improved variety of rice i.e. (2.372 g). Highest sterility was obtained in field of NE for Ramdhan i.e. $27.9 \%$ which was followed by treatment GRI i.e. $(27.7 \%)$, NEH i.e. (16.65\%) and GRH i.e. (14.57\%). 

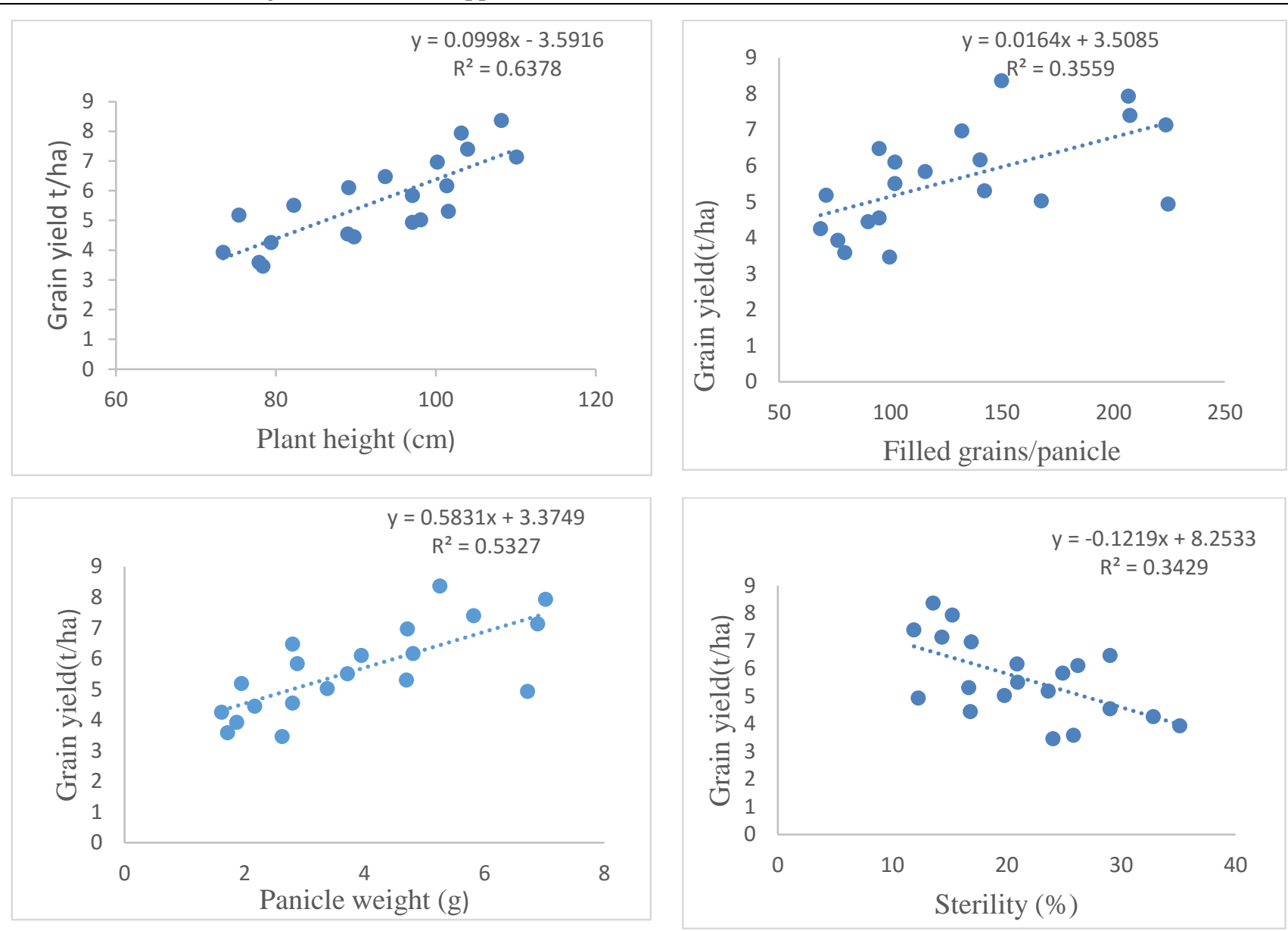

Fig. 1: Relationship of grain yield with plant height, filled grains/panicle, panicle weight and sterility $(\%)$

\section{Conclusion}

From the trial, highest grain yield i.e.,(7.36 tonha-1) was obtained from NE field for the US-382. With the use of NE based fertilizer recommendation, we can gain the highest attainable yield as shown by the NE software .Higher productivity of hybrid rice was obtained from NE based recommendation as it makes use of $4 \mathrm{R}$ (the right source of fertilizer , at right time, in right amount and in right place). Increased in productivity ultimately results in fulfilling the growing demand for rice .Thus, NE recommendation was found better over GR and FFP and further hybrid variety showed significantly higher yield as compared to improved variety.

\section{Acknowledgments}

We would like to pay our sincere gratitude to FORWARD Nepal, NRNA Australia, International Plant Nutrition Institute (IPNI) for providing the platform of research and especially very thankful to Dr. Jagdish Timsina coordinator of research project, Dr. K. Majumdar of IPNI for their kindness and sustained support during my study period

\section{Reference}

Dobermann A, Abdulrachman S, Gines HC, Wang G, Nagarajan R, Satawatananont S, Son TT, Tan PS, Tiem LV, Simbahan GC and Olk DC (1996) Internal nutrient efficiencies of irrigated lowland rice in tropical and subtropical Asia. Field Crops Res. 63:113-138.

Dobermann A, Witt C and Dawe D (2004) Increasing productivity of intensive rice systems through Site-Specific Nutrient Management. Science Publishers, Inc., International Rice Research Institute, Enfield, N.H. (USA) and Los Baños (Philippines)

Haq MT, Sattar MA and Hasain MM (2002) Effects of fertilizers and pesticides on growth and yield of rice. Online Journal of Biological Sciences 2(2): 84-88. DOI: $10.3923 /$ jbs.2002.84.88

Ladha JK, Pathak H, Krupnik TJ, Six J and van Kessel C (2005) Efficiency of fertilizer nitrogen in cereal production: retrospect and prospects. Advances in Agronomy 87: 85156. DOI: $10.1016 / \mathrm{S} 0065-2113(05) 87003-8$

MoAD (2014/15) Cost, Production and Price Spread of Cereal Crops in Nepal: A time series analysis 2071/2072 (2014/2015. Market Research \& Statistics Management Program Hariharbhawan, Lalitpur. pp 1-174 
NARC (Nepal Agricultural Research Council), Khumaltar. 2013. NARC, Annual Report 2012/2013, Khumaltar, Lalitpur, Nepal.

Salam MA, Lucy F, Kabir MH and Khan AR 2011. Effect of different doses of fertilizers on yield and yield components of two varieties of boro rice. J. Agro. Environ. 5(2): 5356.

Sapkota TB, Majumdar K, Jat ML, Kumar A, Bishnoi DK, McDonald AJ and Pampolino M (2014) Precision nutrient management in conservation agriculture based wheat production of Northwest India: Profitability, nutrient use efficiency and environmental footprint. Field Crops Res. 155: 233-244. DOI: 10.1016/j.fcr.2013.09.001

Satyanarayana T, Majumdar K, Pampolino M, Johnston AM, Jat ML, Kuchanur P, Sreelatha D, Sekhar JC, Kumar Y, Maheswaran R, Karthikeyan R, Velayutahm A, Dheebakaran G, Vallalkannan S, Sherene Ranjith TH, Shivamurthy D, Aladakatti YR, Chiplonkar D, Gupta R, Biradar DP, Jeyaraman S and Patil SG (2012) Nutrient Expert@: A tool to optimize nutrient use and improve productivity of maize. Better Crops. South Asia. 